\title{
DINAMIKA TAJDID DALAM DAKWAH MUHAMMADIYAH
}

\author{
Desvian Bandarsyah \\ Pendidikan Sejarah FKIP Universitas Muhammadiyah Prof. HAMKA \\ email: d.bandarsyah@gamail.com
}

\begin{abstract}
Abstrak
Muhammadiyah tidak sekedar hadir sebagai fenomena gerakan sosial biasa. Gerakan keagamaan hadir dengan nilai-nilai sebagai ideologi gerakan berbasis pada sistem keyakinan (belief system based) dan religious movement. Secara historis empiris tajdid Muhammadiyah berangkat dari teropong pemikiran terhadap konteks sosiokultural-spiritual yang berakar pada kontekstualisasi gagasan masa lalu dan masa depan. Ide-ide tantangan masa lalu menjadikan tajdid itu berorientasi jauh lebih ke belakang, yaitu diarahkan pada gerakan purifikasi ajaran Islam dengan menjalankan gerakan pemurnian ajaran Islam. Sumber utama dari gerakan ini adalah Al-Qur'an, Hadist dan Sunnah Rasul yang dijadikan tuntunan dalam kehidupan.
\end{abstract}

Kata kunci: dinamika, tajdid, dakwah Muhammadiyah

\begin{abstract}
Muhammadiyah is not just present as a phenomenon of social movements regular. Religious movements present values as ideological movement based on the belief system (belief system based) and the religious movement. Historically empirical tajdid Muhammadiyah set of ideas to the socio-cultural-spiritual ideas that are rooted in the contextualization of the past and the future. The ideas of the past challenges tajid make it much more backward-oriented, which is directed at the movement of purification of Islam by running the Islamic purification movement. The main source of this movement is the Qur'an, the Hadith and Sunnah are used as guidance in life.
\end{abstract}

Keywords: dynamics, tajdid, Muhammadiyah propaganda

\section{PENDAHULUAN}

Muhammadiyah dalam konteks historis, sebagaimana sejarah gerakan keagamaan pada umumnya, tentu bukan sekedar hadir sebagai fenomena gerakan sosial biasa. Gerakan keagamaan hadir dengan nilai-nilai sebagai ideologi gerakan berbasis pada sistem keyakinan (belief system based) yang mendorong lahirnya militansi dalam gerakan dimaksud. Pada bagian lainnya, Muhamadiyah sebagai religious movement juga mengandung dan menawarkan nilai-nilai pengetahuan, keorganisasian, model aksi, dan pelaku gerakan dalam sistem sosial masyarakatnya.

Berkembangnya ideologi transnasional secara masif dalam tataran global menyusul berakhirnya Perang Dingin, telah mendorong Muhammadiyah perlu melakukan kajian terhadap dimensi dan kompleksitas dakwah yang dihadapinya. Lintasan sejarah panjang memberikan informasi kepada kita bahwa kemampuan Muhammadiyah menghadapi berbagai perubahan adalah antara lain 
disebabkan kecerdasan yang dimiliki dalam menyikapi berbagai perubahan tersebut.

Di awali dengan adanya perluasan kristenisasi yang terjadi bersamaan dengan perluasan kekuasaan kolonial yang hegemonik pada masyarakat pribumi yang agama Islam, juga tekanan politis, ekonomis, sosial, maupun kultural yang dialami oleh masyarakat luas, telah menyebabkan ide kritis terhadap konialisme Belanda berlangsung semakin masif dari elite Islam di Jawa (M.C Ricklefs, 2008: 326.). Salah satu tokoh sentralnya adalah $\mathrm{KH}$. Ahmad Dahlan, yang melihat ketimpangan stratifikasi masyarakat kolonial, di mana penduduk pribumi menempati posisi yang paling rendah dan tertindas, sedangkan orang Eropa menduduki lapisan paling atas yang disusul orang Cina dan Arab, telah mendorong pendirian Muhammadiyah secara kuat.

Realitas ini yang mendorong tekad Ahmad Dahlan untuk mendirikan dan menjalankan dakwah dengan membangun dan mengembangkan infrastruktur dan suprastruktur organisasi, dalam konteks kaderisasi dan ideologi serta teologi. Muhammadiyah berusaha membangun dasar pemikiran teologis dan filosofis sebagai dasar pijakan bagi gerakannya di masa depan. Paradigma pemikiran keislaman pada masa lalu yang lebih bersifat bayani (tekstual normatif) menuntut pengayaan paradigma irfani (sufistik spiritual) dan paradigma burhani (empirik kontekstual), (Muhammad Azhar, 2005: 11) agar dakwah Muhammadiyah memiliki spektrum jangkauan kedalaman dan penyelesaian masalah sosial penting bagi gerakan yang dijalankan segenap stakeholder Persyarikatan.

\section{PEMBAHASAN}

Tajdid Sebagai Landasan Dakwah Muhammadiyah

Secara historis empiris tajdid Muhammadiyah berangkat dari teropong pemikiran terhadap konteks sosiokultural-spiritual yang berakar pada kontekstualisasi gagasan masa lalu dan masa depan. Ide-ide tantangan masa lalu menjadikan tajid itu berorientasi jauh lebih ke belakang, yaitu diarahkan pada gerakan purifikasi ajaran Islam dengan menjalankan gerakan pemurnian ajaran Islam. Sumber utama dari gerakan ini adalah Al-Qur'an dan terutama Hadist dan Sunnah Rasul yang dijadikan tuntunan dalam menjelaskan berbagai fenomena tahayyul, bid'ah, churafat (TBC). Dimensi pertama ini, meskipun masih menjadi konsensus dalam gerakan ber-Muhammadiyah, namun strategi yang digunakan dan dikembangkan lebih softly dan cenderung tidak mendorong konflik sebagaimana di awal kelahirannya. Pendekatan paradigma Bayani tidak lagi melulu menjadi mainstream utama dari 
pola gerakan Muhammadiyah pada hari ini.

Dimensi yang kedua, tajdid diarahkan pada dimensi kekinian dan masa depan. Realitas sosial dan Ide-ide dan tantangan ke depan dalam masyarakat menjadi wacana dan pemikiran dakwah Muhammadiyah. Aspek imperatif dan substansif menjadi bergeser dari paradigma bayani yang dominan menuju paradigma irfani yang memberikan ruang bagi perenungan realitas sosial dan kultural terhadap masyarakat dan dakwahnya, sekaligus juga menjalankan paradigma burhani yang empirik kontekstual. Berbagai isu sosial politik dan keagamaan menjadi konsen utama dakwah Muhammadiyah. Ruang bergeraknya menjadi semakin luas seiring dengan berkembangnya dinamika dalam masyarakat bangsa dan negara. Maka dewasa ini kita menyaksikan bagaimana Muhammadiyah menjalankan jihad konstitusional dan mulai mengembangkan bisnis dengan menghimpun berbagai saudagar yang berada dalam lingkaran Muhammadiyah yang selama ini berada dalam di luar jangkauan dan pemikirannya.

Perkembangan itu, secara historissosio-kultural memiliki ikatan pemikiran dan gagasan serta idealisme yang kokoh dengan pendirinya, Ahmad Dahlan. Misalnya, bagaimana tajdid menjadi roh dari kesadaran dan gerakan Muhammadiyah, nampak secara kuat pada pilihan dakwah yang diambil
Ahmad Dahlan ketika memutuskan gerakan dakwah amar ma'ruf nahi mungkar menjadi pilihan satu-satunya yang diyakini, dan itu dilaksanakan dengan konsistensi yang tinggi. Ini menjadi terobosan paling penting yang kemudian terbukti beberapa tahun setelahnya. Pilihannya untuk mendirikan organisasi keagamaan dengan menitikberatkan pada dakwah pendidikan bagi masyarakat pada masa itu menjadi pilihan strategis dan jenius yang diambil Ahmad Dahlan.

Pilihan itu bukan didasarkan pada kajian literatur Islam klasik sebagaimana ditujukkan oleh sejarah dan juga tidak diperoleh melalui inspirasi dan informasi dari konsepkonsep teologis atau kalam klasik yang telah mapan dalam berbagai literatur khasanah intelektual Islam klasik, tetapi lebih pada usaha praksis yang didorong oleh kesadaran melihat realitas masyarakat dan kemajuan dunia barat pada masa itu (Lihat lebih jauh pada M. Amin Abdullah. 1995). Ini dimungkinkan karena persinggungan Ahmad Dahlan dengan berbagai spektrum pemikiran dan pengalaman yang luas pada masa itu.

Menurut Kurzman, gagasan Ahmad Dahlan mengenai pendidikan adalah ajaran yang bersumber dari Islam menyangkut kebaikan etika dan kebahagiaan manusia. la mengatakan, bahwa pengetahuan tentang kesatuan manusia adalah sebuah pengetahuan 
yang amat besar, meliputi bumi dan kemanusiaan. Apabila manusia melupakan prinsip kemanusiaan tersebut, maka mereka akan hancur dan menghancurkan (Abdul Munir Mulkhan, 2012: 108). Secara kritis gagasan ini mendasarkan pada filosofi Al-Maun sebagai basis ideologi pemikiran dan gerakan.

Dalam konteks itu pemikiran tajdid yang diusung Muhammadiyah memiliki dasar teologis dan filosofis yang kokoh. Secara umum ide pembaharuan yang di tempat dalam sentra pendidikan, menjadi bukti komitmen tajdid Muhammadiyah. Pendidikan menjadi pilihan utama, karena share ide dan gagasan melalui pendidikan menjadi efektif dan bersifat deseminatif ilmu pengetahuan yang mendorong terus reproduktifnya pemikiran pembaharuan. Penyelenggaraan pendidikan Muhammadiyah juga yang diyakini sebagai sarana dalam menjembatani disparitas realitas sosial kebangsaan Indonesia dengan Masyarakat Utama yang dicita-citakan Muhammadiyah sejak berdirinya satu abad lampau.

Dalam konteks nasional gagasan mengenai cita-cita Muhammadiyah itu sejalan dengan tujuan pendidikan nasional yang dirumuskan ke dalam pernyataan luhur, "Membentuk manusia Indonesia yang sempurna, berakhlak mulia, cerdas, kreatif, inovatif..." maka pada tataran filosofis pragmatisnya perlu dilakukan kajian yang merefleksikan kebutuhan dan sekaligus tantangan bagi pendidikan Muhammadiyah ke depan, sekaligus juga sebagai koreksi Muhammadiyah terhadap pendidikan nasional yang semakin menjauh dari cita-cita konstitusi (Desvian Bandarsyah. Suara Muhammadiyah edisi 3 tahun 2010).

Secara umum dapat dipahami, kesadaran Muhammadiyah dalam memilih strategi dakwahnya mengambil jalan kultural mencerminkan keyakinannya bahwa Masyarakat Utama hanya dapat diwujudkan melalui kerjakerja strategis berupa pembaharuan dan pemberdayaan dalam menyelenggarakan dan memajukan pendidikan di tengahtengah masyarakat. Atas prinsip dan kesadaran semacam itu, Muhammadiyah perlu memberikan penyegaran terhadap landasan operasional penyelenggaraan pendidikannya.

Walaupun bukan tanpa kritik terhadap pemikiran tajdidnya. Kecenderungan Muhammadiyah yang selama ini diam dan melakukan kerjakerja regular semata sebagai respon atas berbagai kebijakan pendidikan yang diputuskan pemerintah menyebabkan perkembangan

pendidikan Muhammadiyah berada dalam posisi yang aman namun mengandung resiko berupa kehilangan watak pembaharunya, yang dalam tataran ideologis dapat menghambat terselengaranya pencapaian Masyarakat 
Utama yang dicita-citakan. Kondisi ini dialami oleh pendidikan Muhammadiyah sebagai pantulan dari dominasi negara dalam mengelola kepentingan pendidikan (Desvian Bandarsyah. Suara Muhammadiyah edisi 3 tahun 2010). Muhammadiyah perlu mengambil posisi yang berbeda dengan sebelumnya, melalui pemunculan gagasan baru berupa cetak biru pembaharuan pendidikan sebagai bentuk tanggungjawab ideologis dan sosiologis bagi umat, masyarakat, bangsa dan negaranya.

Transformasi Tajdid: Dari Pemikiran ke Perbuatan

Dakwah

Muhammadiyah

merupakan respon terhadap dinamika ke-Indonesia yang dipengaruhi oleh perubahan global, regional, dan lokal. Perubahan dunia yang mendasar sekurang-kurang menawarkan empat hal yang sampai saat ini masih terus berlangsung, dengan berbagai implikasinya. Pertama, kecenderungan ke arah perubahan dalam konstelasi politik global dari konteks bi-polar menuju konteks multi polar. Kondisi ini menggeser paradigma indefenden dan defenden yang selama ini menjadi pola dari relasi antar bangsa, menjadi paradigma interdefendensi yang melibatkan relasi antar negara menjadi semakin terintegrasi ke dalam sistem global.
Ketiga, meningkatnya peranan aktor-aktor non pemerintah dalam tata hubungan antar negara, yang ditandai dengan menguatnya peranan sektor non pemerintah, baik yang diwakili dunia usaha maupun lembaga swadaya masyarakat. Keempat, muncul dan semakin menguatnya isu-isu dalam agenda internasional, seperti lingkungan hidup, demokrasi dan demokratisasi, kebebasan dan hak asasi manusia, serta kesetaraan lintas etnis, budaya, dan gender (Ali Alatas dalam Jakop Oetama, 2000: 3-10). Keempat aspek ini mengalami kecenderungan yang semakin penting di berbagai dunia, termasuk Indonesia.

Sejalan dengan itu, maka proses demokratisasi berkembang menerobos sekat-sekat ketertutupan struktural dan kultural. Gagasan mengenai kebebasan, kesetaraan, dan keadilan telah mengalami peningkatan dari sekedar isu menjadi tuntutan yang niscaya. Berbagai pemerintahan di berbagai negara tidak dapat lagi mengelak dan tunduk pada "aturan" tatanan dunia baru, sehingga dunia menjadi berlarian dalam arus deras perubahan yang tidak terelakkan untuk memenuhi tuntutan dimaksud.

Gerakan Muhammadiyah sebagai gejala perkotaan, juga tidak dapat menghindarinya, maka respon yang tepat perlu diambil dan dijalankan dengan cepat, terarah, dan efektif, serta keyakinan dan keberanian dalam 
mensikapi berbagai perubahan yang berlangsung.

Kemampuan Muhammadiyah melintasi abad keduanya dengan baik, sangat ditentukan oleh respon semacam itu. Itulah mengapa diperlukan positioning yang kuat berkenaan dengan dakwah dan gerakannya, sehingga Muhammadiyah mampu beradaptasi dengan perubahan yang terjadi. Hal lain adalah kemampuannya mengelola berbagai isu keagamaan, kemasyarakatan dan kebangsaan serta perkembangan global, telah memberikan kontribusi besar terhadap peningkatan posisi tawarnya dalam pergumulan sosio-kultural-spiritual dan politik ke-Indonesiaan dewasa ini (Mitsuo Nakamura dalam: Din Syamsuddin (ed.), 1990: 123-142).

Dalam konteks itu, sejak kelahirannya hingga era modern ini, dapat dikatakan bahwa telah terjadi transformasi struktural dalam Muhammadiyah dari paradigma tajid pemikiran kepada paradigma tajdid perbuatan. Hal ini dapat dipahami dalam kerangka tahapan dari proses yang dijalaninya, yaitu bahwa gerakan Muhammadiyah dalam berbagai dimensi aspek dakwah merupakan transformasi dari paradigma bayani yang bersifat tekstual normatif kepada paradigma burhani yang empirik kontekstual.

$$
\text { Proses ini sebagai }
$$

pengejawantahan dari pantulan Tajdid sebagai mata pisau tajam yang membedah berbagai peroblema empiris yang dihadapi dalam dakwahnya, perlu mengalami tranformasi. gagasan pembaharuan yang mendahuluinya, tetapi juga pembaharuan itu telah melahirkan konsekwensi antara lain, terpusatnya Muhammadiyah terhadap amal usaha sebagai dakwah, sehingga cenderung terjebak dalam rutinitas gerakan yang mendorong Muhammadiyah lamban dalam merefleksikan paradigma pembaharuan yang dicetuskannya, sehingga mengakibatkan amal usaha melakukan kerja amal yang cenderung mengalami polarisasi konflik idealisme dengan ide awalnya. Walaupun kegelisahan semacam ini telah mendapatkan porsi yang memadai untuk dikaji dan diatasi dalam struktur Persyarikatan, sebagaimana yang disinggung sebelumnya.

Bagian imperatifnya adalah kemampuan adaptif dari Tajdid yang terus mengalami transformasi seiring dinamika yang dihadapi, perlu mendapat ruang yang besar. Tajdid sebagai mata pisau tajam yang membedah berbagai peroblema empiris yang dihadapi dalam dakwahnya, perlu ditanamkan kepada setiap kadernya, sehingga dakwah Muhammadiyah dapat berkembang semakin maju dalam mengawal perubahan masyarakat Indonesia menjadi lebih baik lagi. Tanpa tajdid, bukan tidak mungkin pada abad keduanya, Muhammadiyah akan 
menjelma menjadi raksasa yang lamban dalam merespon kehidupan, atau bahkan artefak sejarah semata.

\section{PENUTUP}

Tajidid Muhammadiyah berakar pada konteks historis dan dinamika kemodernan. Dalam menjalankan dakwahnya, pertimbangan masa lalu yang sarat dengan nilai etik sosial dan spiritual dan kondisi kekinian yang sarat dengan inovasi dan persaingan selalu menjadi dasar pertimbangan utama dalam menjalankan dakwah besar yang digeluti. Muhammadiyah mengambil dan menjalankan peran tajdidnya dalam konteks memberikan kemaslahatan umat.

Sejalan dengan itu tajdid
membutuhkan ruang untuk terus
dimodifikasi dan dikembangkan.
Pemikiran terbuka Muhammadiyah
sebagai ciri utama purifikasi dan
dinamika kemodernan, menjadi modal
utama bagi setiap kader dan penggiat
Persyarikatan untuk mengabdikan diri di
dalamnya, hal ini disadari karena
pembaharuan menjadi pilihan penting
untuk menjadi lokomotif perubahan
masyarakat, bangsa dan negara.

\section{DAFTAR PUSTAKA}

Abdullah, M. Amin. 1995. Pendekatan Teologis Dalam Memahami Muhammadiyah. Dalam: Kelompok Studi Lingkaran (ed.). Intelektualisme Muhammadiyah
Menyongsong Era Baru. Bandung: Mizan \& KSL.

Alatas, Ali. "Tatanan Politik Dunia Abad XXI", dalam: Jakop Oetama. 2000. Indonesia abad XXI di Tengah Kepungan Perubahan Global. Jakarta: KOMPAS.

Azhar, Muhammad. 2005. Post Modernisme Muhammadiyah. Yogyakarta: Suara Muhammadiyah,

Bandarsyah, Desvian. 2010. Tajdid Pendidikan Bagi Muhammadiyah. Dalam: Suara Muhammadiyah edisi 3 tahun 2010.

Mulkhan, Abdul Munir. 2012. Jejak Pembaharuan Sosial dan Kemanusiaan Kiai Ahmad Dahlan. Jakarta: KOMPAS.

Nakamura, Mitsuo. Muhammadiyah Sebagai Gejala Perkotaan: Suatu Observasi Tentang Kontras Pedesaan-Perkotaan dalam Gerakan Sosial Islam. Dalam: Din Syamsuddin $\quad$ (ed.). 1990. Muhammadiyah Kini dan Esok. Jakarta: Pustaka Panjimas, hal. 123-142.

Ricklefs, M.C. 2008. Sejarah Indonesia Modern 1200-2008. Jakarta: Ikrar Mandiri Abadi. 
Dinamika Tajdid dalam Dakwah Muhammadiyah, Desvian Bandarsyah, 67-74 